\title{
Involvement of Akt/NF-kB pathway in antitumor effects of parthenolide on glioblastoma cells in vitro and in vivo
}

\author{
Hiromichi Nakabayashi $^{{ }^{*}}$ and Keiji Shimizu ${ }^{2}$
}

\begin{abstract}
Background: Glioblastoma is the most common and most aggressive form of malignant glioma and is very difficult to treat. Controlling tumour cell invasion and angiogenesis is essential to improve the prognosis of glioblastoma patients. Since constitutive activation of nuclear factor-KB (NF-KB) is necessary for tumour progression, NF-KB may be an important pharmacological target for this disease. Our study aimed to evaluate the antitumour effects of parthenolide, a NF-KB inhibitor, in two human glioblastoma cell lines (U87MG and U373) and in glioblastoma xenografts. Furthermore, we aimed to investigate the molecular mechanisms underlying these effects.

Methods: The anti-invasive and anti-angiogenic effects of parthenolide were analysed using in vitro invasion and angiogenesis assays. Parthenolide-induced growth inhibition of glioblastoma cells in vitro was determined using the MTT (methyl thiazolyl tetrazolium) assay. In addition, the effect of parthenolide on orthotropic implantation in vivo was evaluated using an intracerebral human glioblastoma xenograft model.

Results: We found that parthenolide suppresses proliferation, invasion, and tumour- induced angiogenesis of glioblastoma cells. Molecular studies demonstrated that parthenolide suppresses gene and protein expression of angiogenic factors. Furthermore, parthenolide reduced Akt phosphorylation and activated mitochondrial signalling, suggesting that the antitumour function of parthenolide may be mediated not only by the inhibition of NF-KB but also by the inhibition of Akt signalling and the activation of apoptotic proteins. Parthenolide suppressed neovascularity and tumour growth in glioblastoma xenografts.
\end{abstract}

Conclusion: The present study identified parthenolide as a new therapeutic agent for glioblastomas.

Keywords: Parthenolide, Glioblastoma, NF-KB, Invasion, Angiogenesis

\section{Background}

The serine/threonine kinase Akt, a downstream effector of phosphatidylinositol 3-kinase (PI3K), is involved in cell survival and anti-apoptotic signalling [1]. In a variety of human tumours, including glioblastoma, Akt is constitutively activated due to mutation or deletion of the phosphatase and tensin homologue (PTEN), a major negative regulator of the PI3K/Akt signal pathway $[2,3]$. The PTEN mutation frequency in glioblastoma is reported to be as high as $80 \%$ [3]. Recent studies have demonstrated that PI3K/Akt induction of cell survival

\footnotetext{
* Correspondence: blue_flare17@yahoo.co.jp

${ }^{1}$ Human Biology, Department of Health Sciences, Oita University of Nursing and Sciences, 2944-9 Megusuno, Oita 870-1201, Japan

Full list of author information is available at the end of the article
}

signals is mediated, in part, through the activation of the nuclear factor kappa B (NF-kB) transcription factor [4]. $\mathrm{NF}-\mathrm{kB}$ is linked to various signal transduction pathways and to transcription activation events that mediate cell proliferation, cell migration, and angiogenesis $[5,6]$. Among NF- $\mathrm{kB}$-regulated genes [7], matrix metalloproteinase (MMP)-9 is closely associated with tumour invasion and tumour-induced angiogenesis, and vascular endothelial growth factor (VEGF) promotes tumourinduced angiogenesis. Therefore, inhibition of NF- $\mathrm{kB}$ may serve as an effective treatment strategy for many tumours through MMP-9 and VEGF downregulation and disruption of Akt signalling.

Parthenolide, a major sesquiterpene lactone from the plant Tanacetum parthenium, inhibits NF-kB both

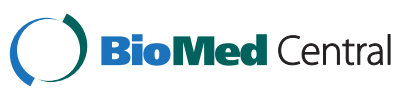


indirectly, by inhibiting the ІкB kinase (ІкK), and directly, by modifying p65 at a key cysteine residue in its activation loop $[8,9]$. Due to its anti-inflammatory and low toxicity properties, parthenolide has been used to treat migraine and rheumatoid arthritis [10]. In addition, many studies have investigated the effect of parthenolide treatment on human malignancies [5-7,9], although only two have examined the effect of parthenolide on glioblastoma cell proliferation in vitro [11,12]. However, their results were contradictory. Anderson et al. reported that parthenolide inhibition of glioblastoma cell proliferation is independent of the NF- $\mathrm{kB}$ pathway [11]. In contrast, Zanotto-Filho et al. reported that parthenolideinduced glioblastoma cell death is mediated by NF- $\mathrm{kB}$ inhibition [12]. We, therefore, aimed to clarify the mechanism involved in parthenolide inhibition of glioblastoma cell proliferation in vitro, and to examine the in vivo effect of parthenolide on tumour growth by using a xenograft model of glioblastoma. We also aimed to evaluate the effect of parthenolide on invasion capacity and tumour-induced angiogenesis in the PTEN-mutant human glioblastoma cell lines U87MG [13] and U373 [14]. To the best of our knowledge, this study is the first to investigate the antitumour effects of parthenolide on human glioblastoma in vivo, and to define the antiinvasive and anti-angiogenic effects of parthenolide treatment on glioblastoma cells in vitro.

\section{Methods}

\section{Cell cultures and drug}

PTEN-mutant human glioblastoma cell lines, U87MG and U373, were obtained from the American Type Culture Collection (Rockville, MD). Glioblastoma cells were maintained in Dulbecco's modified Eagle's medium (DMEM; Gibco, Gaithersburg, MD) supplemented with $10 \%$ foetal bovine serum (FBS; Gibco), penicillin (100 unit $/ \mathrm{mL})$, and streptomycin $(100 \mathrm{mg} / \mathrm{mL})$. Human brain microvascular endothelial cells (HBMECs) were purchased from Science Cell Research Laboratories (Carlsbad, CA) and maintained in RPMI 1640 (Gibco) supplemented with 10\% FBS, 10\% NuSerum (BD Bioscience, Mountain View, CA), modified Eagle's medium nonessential amino acids (1\%) and vitamins (1\%) (Gibco), sodium pyruvate $(1 \mathrm{mM})$, and EC growth supplement $(30 \mu \mathrm{g} / \mathrm{mL})$. Culture flasks were coated with $0.2 \%$ type-I collagen to support the growth of HBMEC monolayers, and experiments were performed using passages 3-10. All cells were cultured at $37^{\circ} \mathrm{C}$ in a humidified atmosphere containing $5 \% \mathrm{CO}_{2}$.

Parthenolide was purchased from Sigma-Aldrich (St. Louis, MO), dissolved in dimethyl sulphoxide (DMSO) to a concentration of $10 \mathrm{mmol} / \mathrm{L}$ and stored in the dark at $-80^{\circ} \mathrm{C}$. A sample of DMSO was stored under the same conditions and used as a control treatment.

\section{ELISA based NF-KB transcription factor activity assay}

Glioblastoma cells were treated with different concentrations $(0.1-50 \mu \mathrm{M})$ of parthenolide for $48 \mathrm{~h}$, and then nuclear extracts were analysed using the TransAM NF- $\mathrm{kB}$ p65 transcription factor assay kit (Active Motif, Carlsbad, $\mathrm{CA}$ ), according to the manufacturer's recommendations. NF- $\mathrm{kB}$ complexes were captured by binding to a consensus $5^{\prime}$-GGGACTTTCC-3' ' oligonucleotide immobilised on a 96-well plate. Bound NF- $\mathrm{B}$ was quantified by incubating with anti-p65 primary antibody followed by horseradish peroxidase (HRP)-conjugated goat anti-rabbit IgG and spectrophotometric detection at a wavelength of $450 \mathrm{~nm}$. Data were expressed as the percentage of NF-kB/DNA binding relative to control cells. The assay was conducted three times for each cell line.

\section{Methyl thiazolyl tetrazolium (MTT) assay}

Glioblastoma cells $\left(1 \times 10^{4}\right.$ cells $)$ were plated into 96well plates in $100 \mu \mathrm{L}$ of DMEM containing 10\% FBS. HBMECs $\left(1 \times 10^{4}\right.$ cells $)$ were plated into 96 -well plates in $100 \mu \mathrm{L}$ of EGM-2 medium (Kurabo, Osaka, Japan) containing $2 \%$ FBS. After $24 \mathrm{~h}$, parthenolide was added to each well at the indicated concentrations (0.1-50 $\mu \mathrm{M})$. After $24 \mathrm{~h}$ or $48 \mathrm{~h}, 50 \mu \mathrm{L}$ of MTT $(2 \mathrm{mg} / \mathrm{mL})$ was added to each well and incubated at $37^{\circ} \mathrm{C}$ for a further $3 \mathrm{~h}$. The $570 \mathrm{~nm}$ absorbance of the dissolved precipitate was measured using a microplate reader. The cell proliferation index was calculated as the ratio of the absorbance of parthenolide-treated cells to that of control cells. The assay was conducted three times for each cell line.

\section{In vitro invasion assay}

In vitro invasion assay was performed using Transwell invasion chambers (BioCoat; BD Biosciences). Glioblastoma cells were cultured in 24-well plates. An insert was used to divide each well of the plate into lower and upper chambers. The bottom of the insert comprised an $8.0-\mu \mathrm{m}$ pore size PET membrane coated with Matrigel (BD Biosciences). The lower chamber was filled with $700 \mu \mathrm{L}$ of DMEM supplemented with $0.1 \%$ bovine serum albumin (BSA) culture medium and human fibronectin $(12.5 \mu \mathrm{g} / \mathrm{mL})$. Subconfluent glioblastoma cells were harvested and resuspended in $500 \mu \mathrm{L}$ of DMEM supplemented with $0.1 \%$ BSA containing parthenolide $(1-50 \mu \mathrm{M})$, and $5.0 \times 10^{4}$ cells/well were added to the upper chamber. After incubation for $23 \mathrm{~h}$, the cells on the upper surface of the filters were removed with cotton swabs. Cells on the lower surface of the filters were fixed using $70 \%$ ethanol, stained with Giemsa stain, and five randomised fields were counted at 200x magnification. The assay was conducted three times for each cell line. 


\section{Tube formation assay using a HBMEC-glioblastoma cell co-culture method}

A modified tube formation assay using culture inserts was used to assess in vitro angiogenesis. Culture plates (24-well) were coated with $300 \mu \mathrm{L} /$ well Matrigel (BD Biosciences) and polymerised at $37^{\circ} \mathrm{C}$ for $30 \mathrm{~min}$. HBMECs in 5\% EBM-2 medium containing FBS were plated $\left(8 \times 10^{4}\right.$ cells/well $)$ into the coated wells, and an insert plate containing a $1-\mu \mathrm{m}$ pore PET membrane (Falcon HTS Multiwell Insert Systems, BD Biosciences) was placed onto the plate. U87MG cells or U377 cells were also cultured in the insert plate to allow soluble angiogenic factors secreted from the glioblastoma cells to reach the endothelial cells in the lower chambers. Parthenolide $(2.5-50 \mu \mathrm{M})$ was added to the culture medium. After 7 days, four randomly selected fields of cells from each treatment were digitally photographed, and the length of the capillary-like structures within the gel matrix was measured using ImageJ software (http:// rsb.info.nih.gov/ij/). The assay was conducted three times for each cell line.

\section{Western blot analysis}

Akt phosphorylation was analysed in glioblastoma cells by western blotting. Glioblastoma cells were starved in serum-free condition for $24 \mathrm{~h}$, stimulated with $5 \mathrm{ng} / \mathrm{mL}$ PMA for $45 \mathrm{~min}$, and then treated with parthenolide $(2.5-10 \mu \mathrm{M})$ for $2 \mathrm{~h}$. Control cells were not stimulated with PMA. Cells were harvested in buffer containing $50 \mathrm{mM}$ Tris- $\mathrm{HCl}$ (pH 7.4), $150 \mathrm{mM} \mathrm{NaCl}, 1 \mathrm{mM}$ EDTA, $1 \%(\mathrm{v} / \mathrm{v})$ Triton X-100, and protease and phosphatase inhibitors (Sigma- Aldrich). Protein concentration was measured using the Bradford assay with a BSA standard. Cell lysate samples $(50 \mu \mathrm{g})$ were separated by $10 \%$ SDSPAGE and transferred onto nitrocellulose membranes. Membranes were incubated overnight at $4^{\circ} \mathrm{C}$ with antiphospho-Akt (Ser473) rabbit antibody (Cell Signalling Technology, Danvers, MA) or total Akt rabbit antibody (Cell Signalling Technology), incubated with HRPconjugated anti-rabbit IgG sheep antibody (GE Healthcare, Piscataway, NJ) for $1 \mathrm{~h}$ at room temperature, and then, the proteins were visualised using a $\mathrm{ECL}^{+} \mathrm{Chemi-}$ luminescence kit (GE Healthcare).

To analyse the effect of parthenolide on Bcl-2 family protein expression and caspase activation, glioblastoma cells were in serum-free condition starved for $24 \mathrm{~h}$, and then treated with parthenolide $(5 \mu \mathrm{M})$ for $6 \mathrm{~h}, 12 \mathrm{~h}$, or $24 \mathrm{~h}$. Bcl-2 family protein expression was assessed by western blotting using anti-Bcl-2 rabbit antibody (Cell Signalling Technology), anti-Bak rabbit antibody (Cell Signalling Technology), and anti-Bax rabbit antibody (Cell Signalling Technology) primary antibodies. Caspase activation was assessed using rabbit anti-caspase 3 (Cell Signalling Technology), rabbit anti-cleaved caspase 3 (Cell
Signalling Technology), rabbit anti-caspase 9 antibody (Cell Signalling Technology), and rabbit anti-cleaved caspase 9 (Cell Signalling Technology) antibodies.

$\beta$-Actin expression, detected using mouse anti- $\beta$-actin monoclonal antibody (Sigma-Aldrich), was used as a loading control. Western blot experiments were performed at least twice, and protein expression was determined by quantitative densitometry.

\section{Evaluation of VEGF and MMP-9 gene expression}

The effect of parthenolide on VEGF and MMP-9 gene expression was analysed by semi-quantitative RT-PCR. Total cellular RNA was extracted from parthenolidetreated $(2.5,5$, or $10 \mu \mathrm{M} ; 12 \mathrm{~h})$ glioblastoma cells using an RNeasy Kit (Qiagen, Valencia, CA) according to the manufacturer's instructions. RT-PCRs were performed using a Takara RNA PCR kit (AMV) ver. 3.0 (Takara, Shiga, Japan) according to the manufacturer's protocol. PCR amplification was performed with the following primers: VEGF forward, 5'-CCATGA ACTTTCTGCTGTCTT-3'; VEGF reverse, 5'-TCGATCGTTCTGTATCAGTCT- 3; MMP-9 forward, 5'GAATTCAGAACCAATCTCGACAGGCA-3'; MMP-9 reverse, 5'-GAATCC AGA ACCAATCTCACCGACAGGCA-3'. As an internal control, a human GAPDH fragment was amplified using the following primers: forward, 5'-TGTTGCCATCAATGACCC-3'; and reverse, 5'-GCAGAGATGATGACCCTT-3'. RT-PCR was performed in at least two independent experiments.

\section{VEGF and MMP-9 secretion from glioblastoma cells}

To determine the effect of parthenolide on the secretion of VEGF and MMP-9 from glioblastoma cells, VEGF and MMP-9 protein levels were measured in the culture medium of parthenolide-treated ( 5 or $10 \mu \mathrm{M} ; 12 \mathrm{~h}$ ) glioblastoma cells by using a VEGF and MMP-9 ELISA kit (GE Healthcare). Data from parthenolide-treated cells were expressed as percentage of untreated controls, and the ELISA assay was conducted three times for each cell line.

\section{Effect of parthenolide on orthotopic cell transplantation}

Athymic female mice (BALB/c nu/nu), aged 6-8 weeks, were obtained from Charles River Japan (Atsugi, Japan). Mice were anaesthetised with an intraperitoneal injection of sodium pentobarbital $(60 \mathrm{mg} / \mathrm{kg})$, and then injected intracerebrally with U87MG cells $\left(1 \times 10^{5}\right)$ through a small hole drilled $2 \mathrm{~mm}$ anterior and $2 \mathrm{~mm}$ lateral to the bregma. Starting immediately after tumour cell transplantation, parthenolide $\left(10 \mathrm{mg} \cdot \mathrm{kg}^{-1} \cdot \mathrm{day}^{-1}\right)$ was administered intraperitoneally to mice $(\mathrm{n}=10)$ every day. Control mice $(\mathrm{n}=10)$ were treated with DMSO vehicle. All mice were sacrificed on day 22, and their brains were excised and snap-frozen in liquid nitrogen. Growth of intracerebral tumours was confirmed by 
histological evaluation. Serial coronal sections $(30 \mu \mathrm{m})$ were cut using a cryo-microtome from the rostral to the caudal edge of tumour-containing brain tissue. Tumour size was estimated in sequential tumour sections by using an Image-Pro system (Media Cybernetics Inc., Silver Spring, MD). All procedures involving animals were approved by the animal care committee of Kochi University and were done in accordance with institutional and Japanese government guidelines for animal experiments.

\section{Histological assessment of xenograft tumours}

For immunohistological examination of xenograft tumours, mice were treated as described above, and their brains were harvested, fixed in buffered formalin, and embedded in paraffin. Paraffin sections $(4 \mu \mathrm{m})$ were deparaffinised and dehydrated. MVD was assessed by counting the number of microvessels in one microscope field (at 200× magnification) following haematoxylin-eosin (HE) staining. Immunohistochemical staining for VEGF and MMP-9 was done by incubating paraffin sections with anti-VEGF (Abcam Inc., Cambridge, MA) and anti-MMP-9 (Abcam Inc.) antibodies, followed by incubation with HRP (DAKO, Glostrup, Denmark) by using the EnVision ${ }^{+}$System, and detection with diaminobenzidine. The percentage of VEGF and MMP-9 immunoreactive cells was determined in 10 high-power microscopy fields.

\section{Statistical analysis}

The statistical significance of ELISA data was analysed using an unpaired Student's t-test. The results of invasion and angiogenesis assays were statistically analysed by one-way analysis of variance (ANOVA). The statistical significance of differences in tumour volume between control and treated mice in the orthotopic implantation model was analysed using unpaired and paired Student's t-tests. For all statistical analyses, a p value of $<0.05$ was considered to be statistically significant. All values are presented as mean \pm standard deviation (SD).

\section{Results}

Parthenolide suppresses NF-KB transcriptional activity and inhibits tumour cell proliferation

In two glioblastoma cell lines treated with parthenolide, we found that NF- $\mathrm{BB}$ transcriptional activity decreased as parthenolide concentration increased (Figure 1; *, p < $0.0001 ; *, \mathrm{p}<0.01)$. Further, we used an MTT assay to investigate the effect of parthenolide treatment on glioblastoma cell proliferation, and found that parthenolide concentrations above $5 \mu \mathrm{M}$ suppress the growth of glioblastoma cells in a dose-dependent manner (Figure 2; *, $\mathrm{p}<0.0001)$.

\section{Parthenolide suppresses tumour cell invasion and tumour-induced angiogenesis in vitro}

We evaluated the inhibitory effect of parthenolide on tumour cell invasion by using U87MG cells (Figure 3A), and observed that the numbers of invading cells decreased as parthenolide concentration increased. Therefore, glioblastoma cell invasion capacity is significantly suppressed by parthenolide (Figure 3B; *, p < $0.0001 ; *, \mathrm{p}<0.01)$. We next evaluated the effect of parthenolide on tumour-induced angiogenesis by using the same cell line (Figure 4A), and found that increasing parthenolide concentrations resulted in a significant decrease in tube length relative to control cells (Figure 4B; *, $\mathrm{p}<0.0001)$.
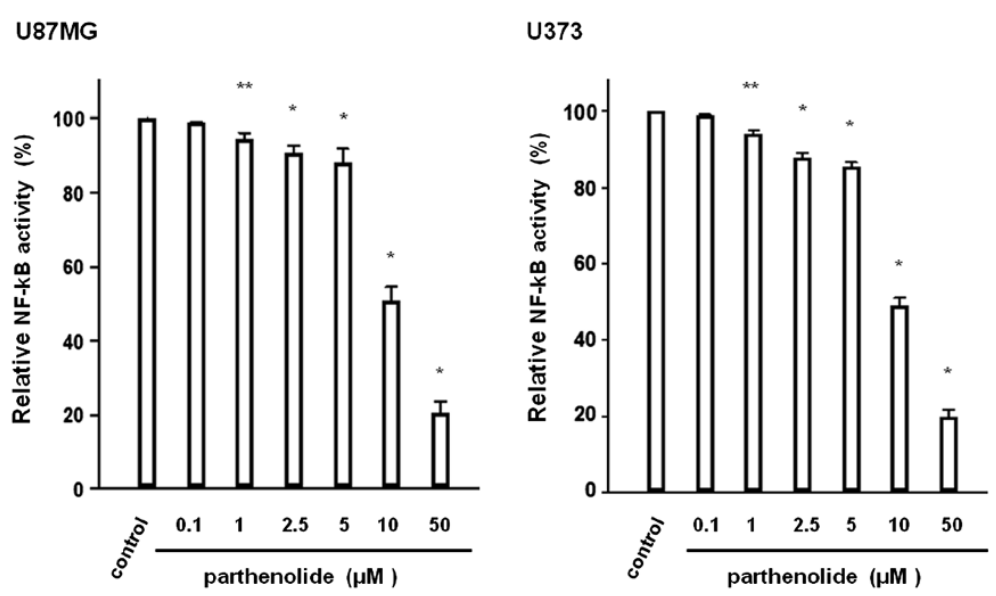

Figure 1 NF-KB transcription factor activity. NF-KB transcriptional activity was analysed in glioblastoma cells $48 \mathrm{~h}$ after treatment with parthenolide by using an ELISA-based assay. The assay showed that the transcriptional activity of NF-KB in the two glioblastoma cell lines decreased as the concentration of parthenolide increased. Data is presented as mean $\pm S D(n=3)$. Points indicate bars $+S D ;{ }^{*}$ indicates $p<0.0001 ;{ }^{* *}$ indicates $p<0.01$. 

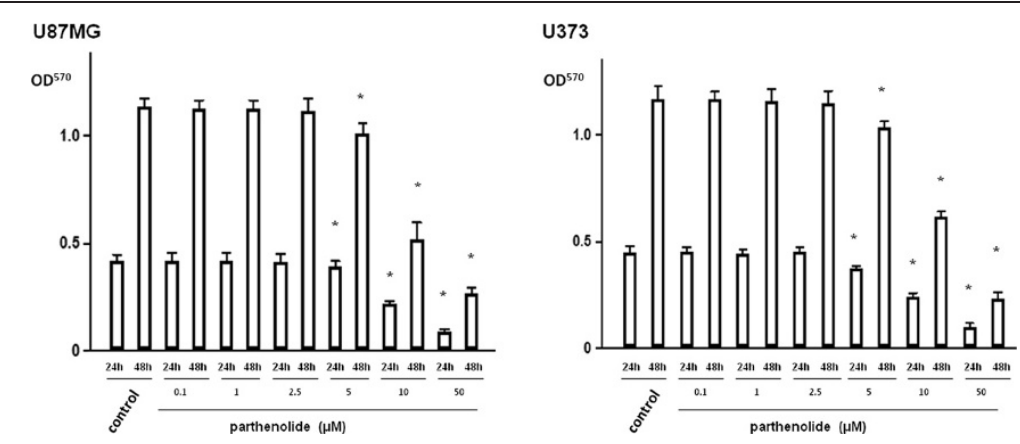

Figure 2 MTT assay. Glioblastoma cells were treated with parthenolide, and cell proliferation was assessed using the MTT assay. Parthenolide inhibited the growth of glioblastoma cells at concentrations above $5 \mu \mathrm{M}$ in a dose-dependent manner. Data is presented as mean \pm SD $(n=3)$. Points indicate bars $+\mathrm{SD} ;{ }^{*}$ indicates $\mathrm{p}<0.0001$

\section{Parthenolide inhibits Akt phosphorylation and Bcl-2 expression and induces caspase activation and Bak and Bax expression}

We observed that a low basal level of Akt phosphorylation was present in glioblastoma cells in the absence of PMA treatment, but that Akt phosphorylation was strongly increased following PMA stimulation. However, parthenolide treatment inhibited PMA-induced Akt phosphorylation in a dose-dependent manner (Figure 5). Furthermore, treatment with parthenolide inhibited Bcl2 protein expression, and increased Bak and Bax protein expression (Figure 6A) and caspase-3 and caspase-9 activation (Figure $6 \mathrm{~B}$ ) in a dose-dependent manner.

\section{Parthenolide suppresses VEGF and MMP-9 gene and protein expression}

We found that parthenolide treatment of glioblastoma cells significantly attenuates VEGF and MMP-9 mRNA expression (Figure 7A) and reduces the secretion of VEGF and MMP-9 protein into the culture medium (Figure 7B; *, $\mathrm{p}<0.0001$ ).

\section{Parthenolide suppresses neovascularisation and xenograft tumour growth}

Xenograft tumour volume was calculated from sequential histological sections (Figure 8A), and revealed that the mean tumour volume in parthenolide-treated mice

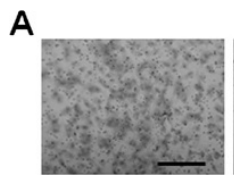

control

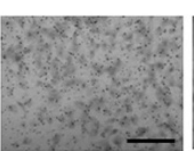

1

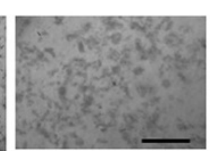

2.5

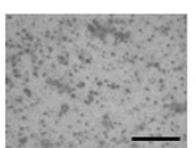

5

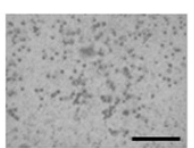

10

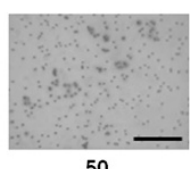

50

parthenolide $(\mu \mathrm{M})$

B
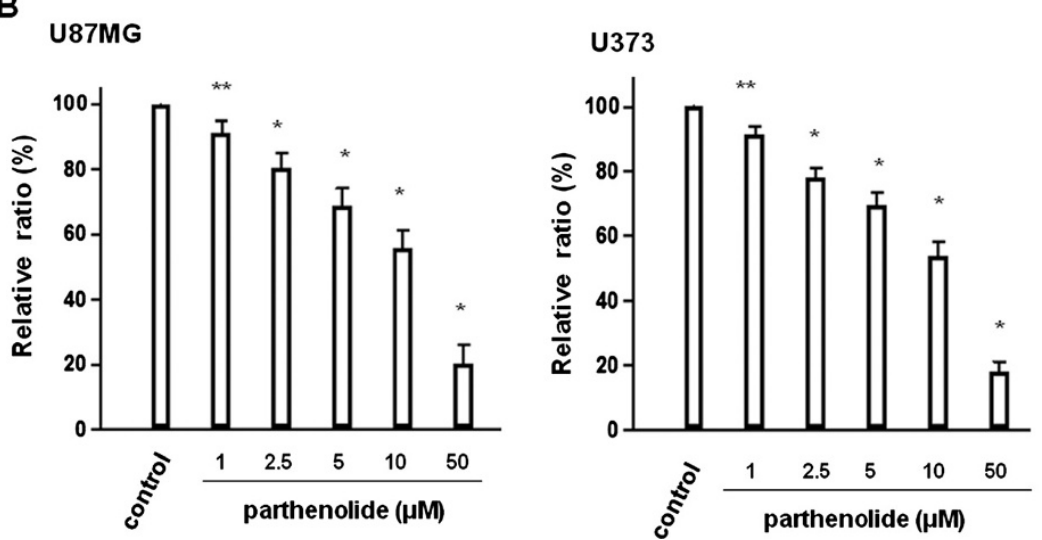

Figure 3 Matrigel invasion assay. Glioblastoma cells were treated with parthenolide, and cell invasion was assessed using a Matrigel invasion assay. (A) Representative U87MG cell data. (B) Number of invading glioblastoma cells relative to control. The number of invaded cells decreased as the concentration of parthenolide increased. $\mathrm{Bar}=100 \mu \mathrm{m}$. Data is presented as mean \pm SD $(n=3)$. Points indicate bars + SD; * indicates $p<0.0001 ;{ }^{* *}$ indicates $p<0.01$. 


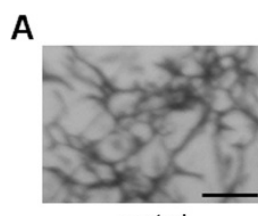

control

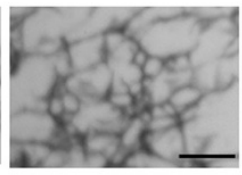

2.5

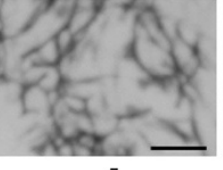

5

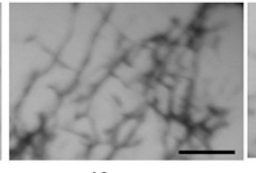

10

parthenolide $(\mu \mathrm{M})$

B

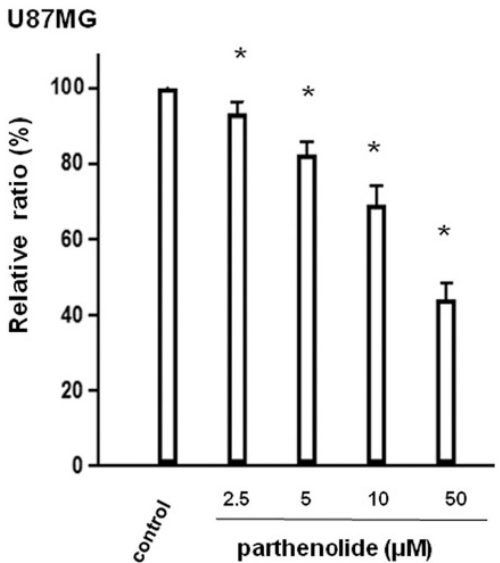

U373

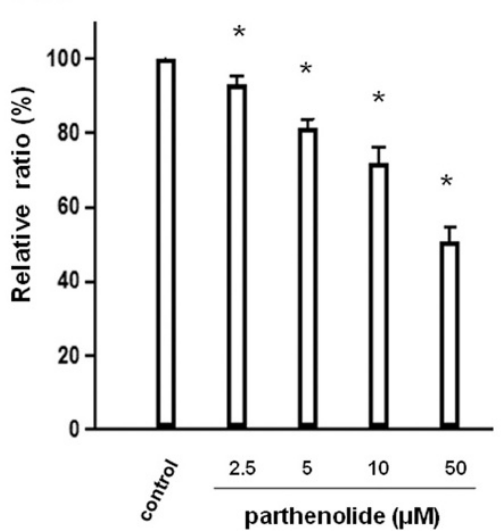

Figure 4 In vitro angiogenesis assay. Glioblastoma cells were treated with parthenolide, and in vitro angiogenesis was assessed using a modified tube formation assay. (A) Representative tube formation data. (B) Tube formation was significantly suppressed by parthenolide in a dose-dependent manner. Data is presented as mean \pm SD $(n=3)$. Points indicate bars + SD; ${ }^{*}$ indicates $p<0.0001$. Bar $=5$ mm.

$\left(45.2 \pm 2.74 \mathrm{~mm}^{3}\right)$ is significantly smaller than in control animals (Figure 8B; $59.5 \pm 3.80 \mathrm{~mm}^{3} ; *$, p < 0.0001). Histological evaluation of $\mathrm{HE}$ staining showed that the mean MVD in parthenolide-treated mice $(4.34 \pm 0.89)$ is significantly lower than in control mice (Figure $8 \mathrm{C}$; $6.52 \pm 0.95 ; \mathrm{p}<0.0001)$. Moreover, VEGF and MMP-9 expression is reduced in the xenografts of parthenolidetreated mice relative to the controls (Figure $8 \mathrm{C}$ ).

\section{Discussion}

NF- $\kappa \mathrm{B}$ plays a pivotal role in tumourigenesis and tumour progression [5,6]. Aberrant or constitutively activated NF- $\mathrm{kB}$ has been detected in human glioblastomas $[15,16]$. The sesquiterpene lactone parthenolide inhibits NF- $\kappa$ B by preventing the degradation of IкB- $\alpha$ and IкB- $\beta$ [17]. We investigated the anti-invasive and antiangiogenic effects of parthenolide on glioblastoma cells

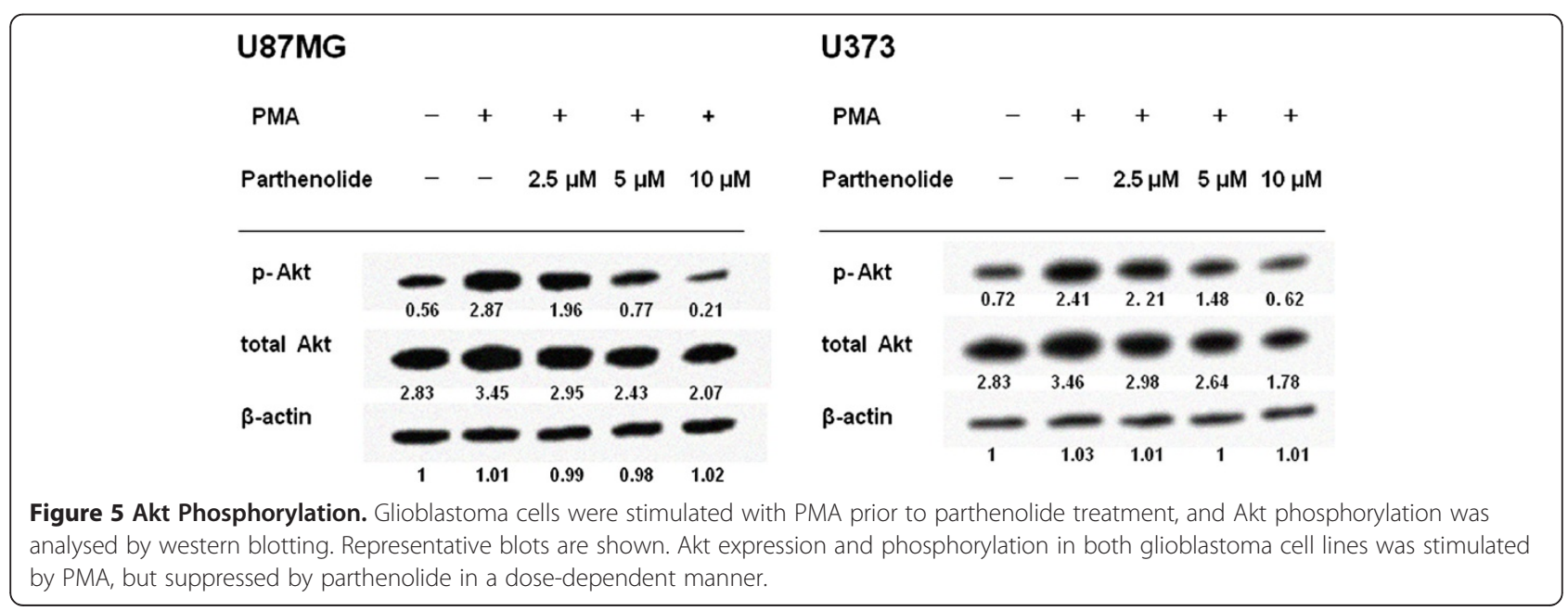


A U87MG

\begin{tabular}{|c|c|c|c|c|}
\hline $\begin{array}{l}\text { parthenolide } \\
(5 \mu \mathrm{M})\end{array}$ & - & $6 \mathrm{hr}$ & $12 \mathrm{hr}$ & $24 \mathrm{hr}$ \\
\hline Bcl-2 & & - & - & - \\
\hline Bak & 0.64 & 0.35 & .0 .22 & $\underline{0.16}$ \\
\hline & $\widehat{0.19}$ & 0.39 & 0.6 & 0.81 \\
\hline Bax & $=$ & 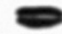 & & \\
\hline$\beta$-actin & & & & 1.09 \\
\hline & 1 & 1.03 & 1.02 & 1.02 \\
\hline
\end{tabular}

B

U87MG

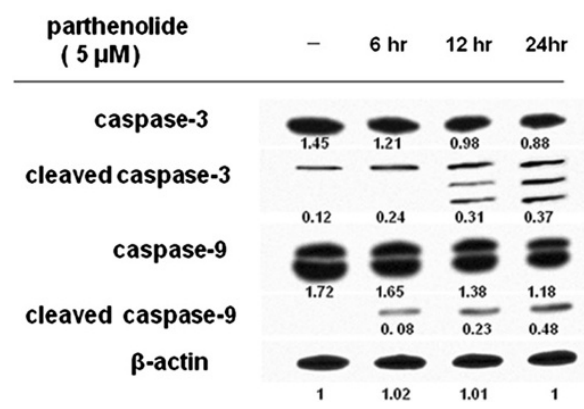

U373

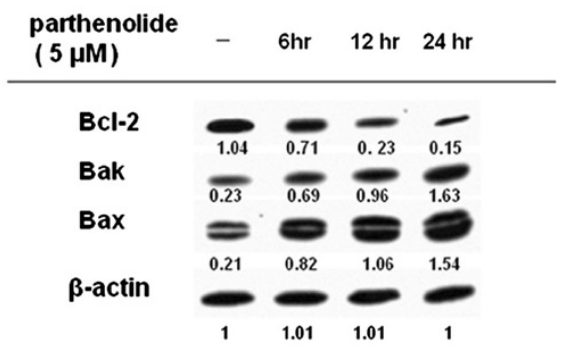

U373

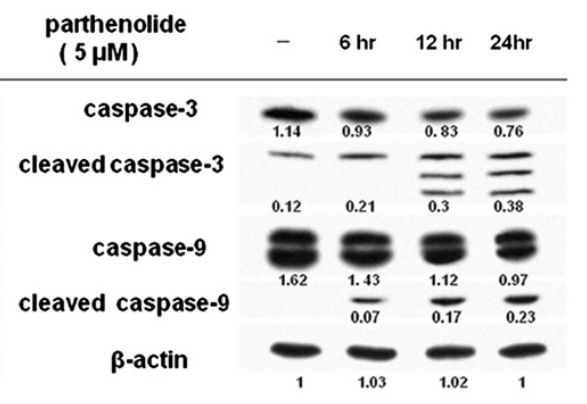

Figure 6 Apoptosis-related protein expressions. The expression of apoptotic proteins in glioblastoma cells stimulated with PMA prior to parthenolide treatment was assessed by western blotting. Representative blots are shown. (A) Analysis showed that parthenolide decreased the protein expression of $\mathrm{BCl}-2$ and increased the protein expression of Bak and Bax in a dose-dependent fashion. (B) Analysis showed that parthenolide induced the activation of caspase-3 and -9 in a dose-dependent manner.

for the first time by using two PTEN-mutant glioblastoma cell lines.

Glioblastoma invasion into normal brain tissues involves disruption of the extracellular matrix (ECM) and the subsequent penetration of tumour cells into adjacent brain structures. This process is partly mediated by the tumour secretion of MMPs, a group of enzymes necessary for ECM degradation and involved in reconstructing ECM components and accelerating tumour cell migration [18]. Through their function as proteolytic enzymes, MMPs destroy the collagen components of the basement membrane (BM) and the ECM, thus disrupting intracellular adhesion, enabling tumour cell invasion, and promoting tumour progression. Elevated levels of MMPs, especially MMP-2 and MMP-9, correlate with glioblastoma tumour aggressiveness, and are believed to play an important role in tumour cell invasion [18-21]. In vivo and in vitro studies have revealed that the inhibiting MMP expression significantly reduces the invasive capacity of glioblastoma cells [22]. Dimerisation of the NF- $\kappa B$ transcription factor at the $\kappa B$ sequence in the MMP-9 promoter initiates MMP-9 transcription, thus upregulating MMP-9 protein expression [23]. Therefore, blocking NF- $\mathrm{kB}$ transcriptional activity by parthenolide may inhibit glioblastoma cell invasion. We found that parthenolide treatment inhibits both glioblastoma cell invasion and MMP-9 expression. These data suggest that parthenolide inhibition of glioblastoma cell invasion is mediated by NF- $\mathrm{kB}$ inhibition.

Tumour-induced angiogenesis is critical for the growth of solid tumours. Numerous studies have reported a correlation between increased intratumour microvessel density (MVD) and the risk of metastasis and/or decreased survival of patients with solid tumours [24-26]. NF- $\mathrm{kB}$ is an important upstream regulator of VEGF [27], a major angiogenic factor that induces endothelial cell proliferation. Glioblastomas are characterised by a high level of angiogenesis, and both VEGF secretion from tumour cells and TNF-alpha-induced NF-kB activation in endothelial cells promote endothelial cell survival by increasing anti-apoptotic gene expression under conditions of serum starvation. These pathways may, therefore, contribute to the maintenance of glioblastoma angiogenesis [28]. Aberrant MMP-9 expression is also implicated in the glioblastoma angiogenesis process. Low basal MMP-9 expression occurs in normal brain 


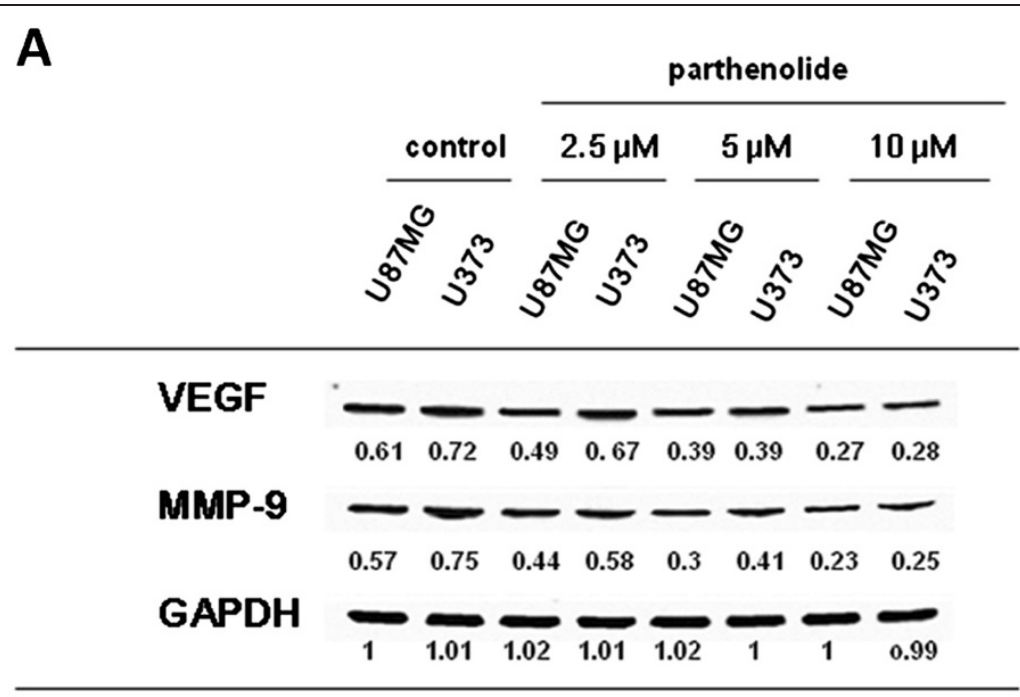

B

U87MG

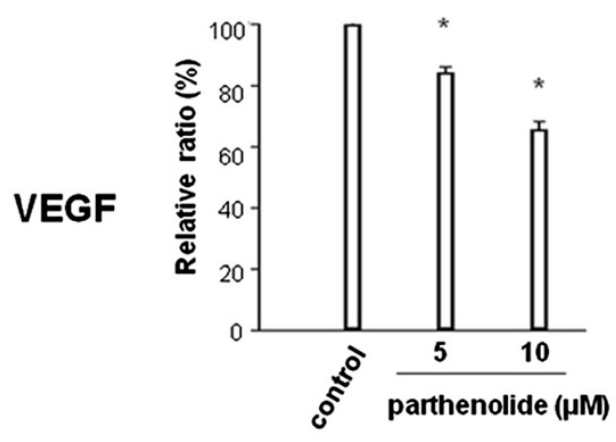

U87MG

MMP-9

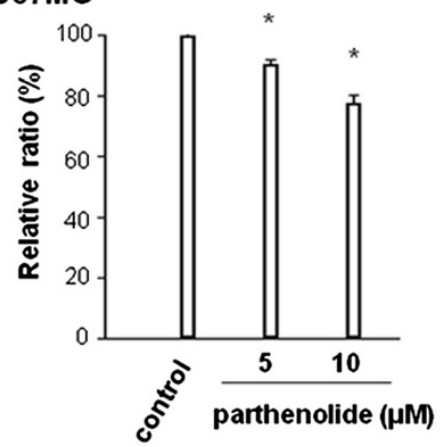

U373

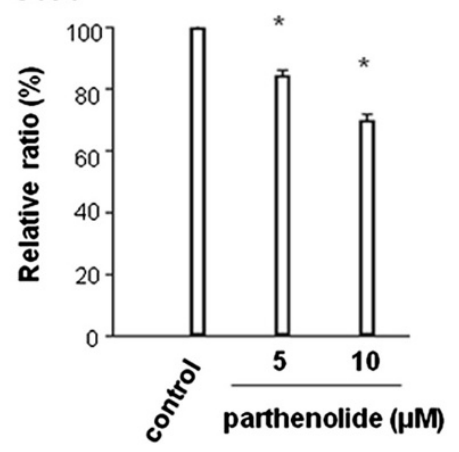

U373

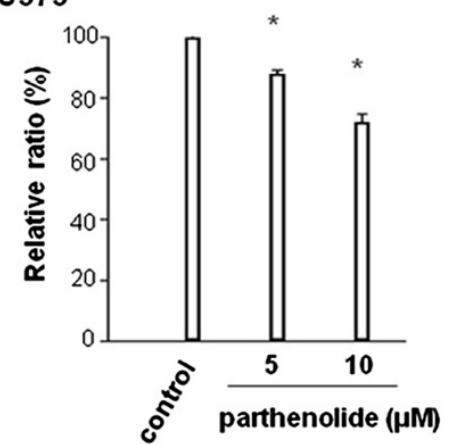

Figure 7 Expression of MMP-9 and VEGF. (A) Glioblastoma cells were treated with parthenolide, and MMP-9 and VEGF gene expression was analysed by semi-quantitative RT-PCR. Parthenolide attenuated the mRNA expression of MMP-9 and VEGF compared with the control. (B) Secretion of MMP-9 and VEGF protein from parthenolide-treated glioblastoma cells was assessed by ELISA. ELISA analysis showed that parthenolide decreased the protein levels of VEGF and MMP-9 in the culture media of glioblastoma cell. Representative data are shown for both assays. * indicates $p<0.0001$.

tissue, but high expression levels are induced in glioblastomas, and are linked to increased tumour cell proliferation [29]. We found that parthenolide suppresses both tumour cell-induced angiogenesis and expression of the NF- $\mathrm{kB}$ targets, i.e., VEGF and MMP-9, in glioblastoma cells. These data suggest that parthenolide suppresses tumour-induced angiogenesis through NF- $\mathrm{kB}$ inhibition.

With regard to tumor proliferation, we observed that parthenolide inhibits glioblastoma cell proliferation in dose-dependent manner. In the present study, cell viability (MTT assay/48h) of U87MG cells decreased to $85 \%$ 


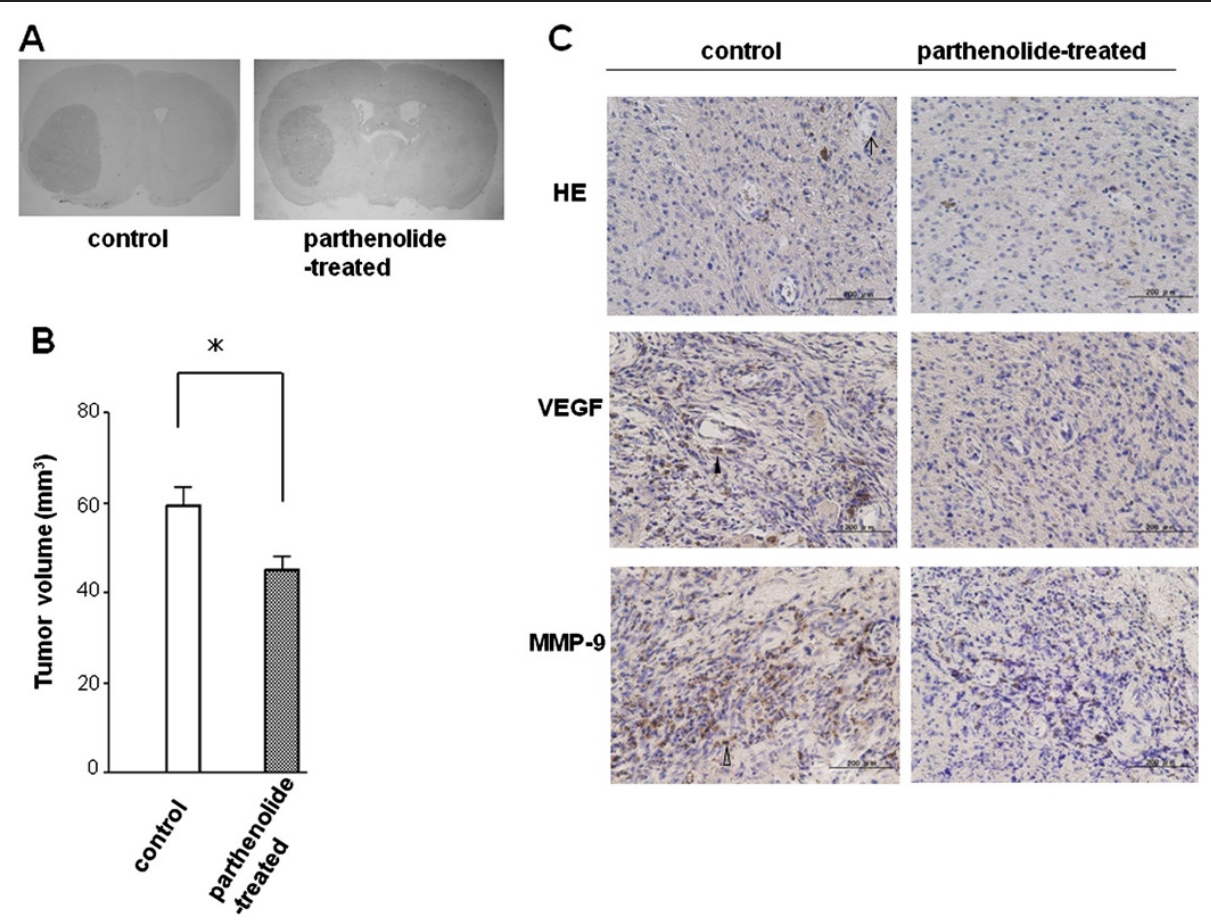

Figure 8 Xenograft mouse model. The effect of parthenolide on in vivo glioblastoma growth was determined using an intracerebral glioblastoma xenograft mouse model. (A) Representative coronal section of mouse brain implanted by glioblastoma cells. (B) Tumour volume analysis revealed that mean tumour volume of the parthenolide group $\left(45.2 \pm 2.74 \mathrm{~mm}^{3}\right)$ was significantly smaller than that of the control group $\left(59.5 \pm 3.80 \mathrm{~mm}^{3}\right)$. * indicates $p<0.0001$. (C) In immunohistochemical stainings VEGF and MMP-9 can be depicted by brown DAB staining (VEGF-positive cell; arrow head, MMP-9-positive cell; white arrow head. Histological evaluation showed that the number of microvessel (arrow) and the expression of VEGF and MMP-9 was significantly lower in the tumours from parthenolide-treated and control mice $(p<0.0001)$. Bar $=200 \mu \mathrm{m}$.

and $45 \%$, after the addition of 5 and $10 \mu \mathrm{M}$ parthenolide, respectively, compared to the control. ZanottoFilho et al. also reported that parthenolide inhibits glioblastoma cell proliferation in dose-dependent fashion and that NF- $\mathrm{kB}$ inhibition by parthenolide significantly correlated in decreases in cell viability of glioblastoma cells [12]. In their report, cell viability (MTT assay/36h) of U138MG cells decreased to $88 \%$ and $34 \%$, after the addition of 5 and $25 \mu \mathrm{M}$ parthenolide, respectively, compared to the control. Our results were close to their research data. On the contrary, Anderson et al. performed proliferation assay using not the MTT but the CCK8 reagent. They reported that cell viability (CCK8 assay/24h) of U87MG cells decreased to about $78 \%$ and about $68 \%$, after the addition of 5 and $10 \mu \mathrm{M}$ parthenolide, respectively, compared to the control and that the inhibitory effect reached the plateau even if the concentration of parthenolide was raised exceeding $20 \mu \mathrm{M}$ [11]. And they also reported that parthenolide was only able to suppress NF- $\kappa \mathrm{B}$ activity by $20-30 \%$. The reason why the inhibitory effect reached the plateau was not clarified. On the other hand, we agree with their opinion that another pathway other than NF-kB is also involved in antitumor effect of parthenolide.
By the way, NF- $\mathrm{kB}$ mediates the expression of antiapoptotic and pro-apoptotic proteins. And most studies have attributed parthenolide suppression of tumour cell proliferation to the induction of apoptotic proteins mediated by NF- $\mathrm{kB}$ inhibition. In colorectal cancer cells, for example, conformational changes in Bax and upregulation of Bak lead to mitochondrial dysfunction and the induction of apoptosis [30]. Recent reports suggest that multiple pathways are involved in parthenolide-induced apoptosis in human cancer cells, including oxidative stress, intracellular thiol depletion, endoplasmic reticulum stress, caspase activation, and mitochondrial dysfunction [31-33]. In addition, parthenolide inhibition of c-Jun $\mathrm{N}$-terminal kinase (JNK) sensitises JB6 murine epidermal cells to ultraviolet B (UVB)-induced apoptosis, suggesting an anti-apoptotic role for JNK [34]. Another report suggests that parthenolide- induced transcriptional suppression of pro-apoptotic genes is mediated by STAT inhibition and acts at both the transcriptional level and by direct inhibition of IKK- $\beta$ [35].

In the present study, we used U87MG and U373 glioblastoma cells containing constitutively activated NF-кB due to PTEN mutation to examine cell survival and apoptosis. We demonstrated that parthenolide inhibits 
Akt phosphorylation, upregulates Bak and Bax, and activates caspase- 3 and caspase- 9 . These results suggest that parthenolide induces apoptosis in glioblastoma cells by activating the mitochondrial apoptosis cascade and reducing survival signals through the inhibition of the Akt pathway. Parthenolide was previously reported to induce apoptosis in colorectal cancer and cholangiocarcinoma cells via the mitochondrial pathway [30,36]. In contrast, NF- $\kappa B$ inhibition by parthenolide markedly enhances the sensitivity of resistant breast cancer tumour cells to tamoxifen through suppression of the Akt pathway [37]. Taken together, the pro-apoptotic effect of parthenolide includes both stimulating the intrinsic apoptotic pathway and modulating expression of $\mathrm{Bcl}-2$ family proteins.

In our in vivo study, parthenolide inhibited the growth of transplanted glioblastoma cells in mouse xenografts. This suggests that inhibitory effect of parthenolide on PTEN-mutant glioblastoma cells is caused by a combination of three mechanisms: suppression of tumour cell invasion, suppression of angiogenesis, and induction of tumour cell apoptosis.

We investigated tumour-induced angiogenesis by using a new in vitro angiogenesis assay that measures EC tube formation in collagen gels. Tumour-induced angiogenesis is usually examined by adding tumour cell medium directly to ECs without direct contact between the endothelial and tumour cells. In contrast, the new method allows the exchange of secreted factors between the endothelial and tumour cells. HUVECs have been used for many angiogenesis studies, especially those including in vitro experiments. However, microvascular endothelial cells from the organ being studied are presumed to be the most appropriate tool for tumour angiogenesis assays. Therefore, for the first time, we investigated the effect of parthenolide on angiogenesis by using HBMECs.

The effect of parthenolide treatment on neuroinflammatory disorders has been examined in the recent years [38-40]. Runmel et al. investigated the potential of parthenolide to reduce brain inflammation and reported that parthenolide can cross the blood-brain barrier [40]. Thus, the combined antitumour and anti-inflammatory properties of parthenolide make it a promising candidate for further studies of neurological diseases.

\section{Conclusion}

We report that parthenolide inhibits tumour progression in PTEN-mutant glioblastoma cells in vitro and in vivo, and suggest that parthenolide has a therapeutic potential as an antitumour agent for glioblastoma.

\section{Competing interests}

The authors declare that they have no competing interests.

\section{Authors' contributions}

HN was responsible for the study design, interpretation of the data and revision of the manuscript. KS supervised the studies and helped to revise the manuscript. Both authors read and approved the final manuscript.

\section{Acknowledgements}

The authors declare that they have no acknowledgements.

\section{Author details}

${ }^{1}$ Human Biology, Department of Health Sciences, Oita University of Nursing and Sciences, 2944-9 Megusuno, Oita 870-1201, Japan. ${ }^{2}$ Department of Neurosurgery, Kochi Medical School Kochi University, 783-8505, Nankoku, Japan.

Received: 13 December 2011 Accepted: 27 September 2012 Published: 5 October 2012

\section{References}

1. Franke TF, Kaplan DR, Cantley LC: PI3K: downsteam AKTion blocks apoptosis. Cell 1997, 88:435-437.

2. Steck PA, Pershouse MA, Jasser $S A$, Yung WK, Lin $H$, Ligon $A H$, Langford LA, Baumgard ML, Hattier T, Davis T, Frye C, Hu R, Swedlund B, Teng DH, Tavtigian SV: Identification of a candidate tumor suppressor gene, MMAC1, at chromosome 10q23.3 that is mutated in multiple advanced cancers. Nat Genet 1997, 15:356-362.

3. Wang SI, PuC J, Li J, Bruce JN, Cairns P, Sidransky D, Parsons R: Somatic mutations of PTEN in glioblastoma multiforme. Cancer Res 1997, 57:4183-4186.

4. Madrid LV, Mayo MW, Reuther JY, Baldwin AS Jr: Akt stimulates the transactivation potential of the RelA/p65 subunit of NF-kB through utilization of the IKB kinase and activation of the mitogen activated protein kinase p38. J Biol Chem 2001, 276:18934-18940.

5. Gilmore TD: Introduction to NF-kappaB: players, pathways, perspectives. Oncogene 2006, 25:6680-6684.

6. Haffner MC, Berlato C, Doppler W: Exploiting our knowledge of NF-kB signaling for treatment of mammary cancer. J Mammary Gland Biol Neoplasia 2006, 11:63-73.

7. Wu JT, Kral JG: The NF- NF- NF-KB/lkB signaling system: A molecular target inbreast cancer therapy. J Surg Res 2005, 123:158-169.

8. Kwok BH, Koh B, Ndubuisi MI, Elofsson M, Crews CM: The anti-inflammatory natural product parthenolide from the medicinal herb Feverfew directly binds to and inhibits IB kinase. Chem Biol 2001, 8:759-766.

9. Hehner SP, Hofmann TG, Droge W, Schmitz ML: The antiinflammatory sesquiterpene lactone parthenolide inhibits NF-B by targeting the IB kinase complex. J Immunol 1999, 163:5617-5623.

10. Heptinstall S: Feverfew-an ancient remedy for modern times? J R Soc Med 1988, 81:373-374.

11. Anderson KN, Bejcek BE: Parthenolide induces apoptosis in glioblastomas without affecting NF-kappaB. J Pharmacol Sci 2008, 106:318-320.

12. Zanotto-Filho A, Braganhol E, Schröder R, de Souza LH, Dalmolin RJ, Pasquali MA, Gelain DP, Battastini AM, Moreira JC: NFKB inhibitors induce cell death in glioblastomas. Biochem Pharmacol 2011, 81:412-424.

13. Cheney IW, Johnson DE, Vaillancourt MT, Avanzini J, Morimoto A, Demers GW, Wills KN, Shabram PW, Bolen JB, Tavtigian SV, Bookstein R: Suppression of tumorigenicity of glioblastoma cells by adenovirus-mediated MMAC1/ PTEN gene transfer. Cancer Res 1998, 58:2331-2334.

14. Morimoto AM, Berson AE, Fujii GH, Teng DH, Tavtigian SV, Bookstein R, Steck PA, Bolen JB: Phenotypic analysis of human glioma cells expressing the MMAC1 tumor suppressor phosphatase. Oncogene 1999, 18:1261-1266.

15. Kanzawa $T$, Ito $H$, Kondo $Y$, Kondo S: Current and Future Gene Therapy for Malignant Gliomas. J Biomed Biotechnol 2003, 2003:25-34.

16. Ravi R, Bedi A: NF-kappaB in cancer-a friend turned foe. Drug Resist Updat 2004, 7:53-67

17. Hehner SP, Heinrich M, Bork PM, Vog M, Ratter F, Lehmann V, SchulzeOsthoff K, Droge W, Schmitz ML: Sesquiterpene lactones specifically inhibit activation of NF-B by preventing the degradation of IKB- $\alpha$ and IKB- $\beta$. J Biol Chem 1998, 273:1288-1297.

18. Rao JS: Molecular mechanisms of glioma invasiveness: the role of proteases. Nat Rev Cancer 2003, 3:489-501.

19. Wild-Bode C, Weller M, Wick W: Molecular determinants of glioma cell migration and invasion. J Neurosurg 2001, 94:978-984. 
20. Kunishio K, Okada M, Matsumoto Y, Nagao S: Matrix metalloproteinase-2 and -9 expression in astrocytic tumors. Brain Tumor Pathol 2003, 20:39-45.

21. Björklund $M$, Kojvunen $E$ : Gelatinase-mediated migration and invasion of cancer cells. Biochim Biophys Acta 2005, 1755:37-69.

22. Kondraganti S, Mohanam S, Chintala SK, Kin Y, Jasti SL, Nirmala C, Lakka SS, Adachi Y, Kyritis AP, All-Osman F, Sawaya R, Fuller GN, Rao JS: Selective suppression of matrix metalloproteinase-9 in human glioblastoma cells by antisense gene transfer impairs glioblastoma cell invasion. Cancer Res 2000, 60:6851-6855.

23. Sato HM, Seiki M: Regulatory mechanism of 92-kDa type IV collagenase gene expression which is associtated with invasiveness of tumor cells. Oncogene 1993, 8:395-405.

24. Van Hoef ME, Knox WF, Dhesi SS, Howell A, Schor AM: Assessment of tumour vascularity as a prognostic factor in lymph node negative invasive breast cancer. Eur J Cancer 1993, 29A:1141-1145.

25. Gasparini G, Weidner N, Maluta S, Pozza F, Boracchi P, Mezzetti M, Testolin A, Bevilacqua P: Intratumoral microvessel density and p53 protein: correlation with metastasis in head-and-neck squamous-cell carcinoma. Int J Cancer 1993, 55:739-744

26. Leon SP, Folkerth RD, Black PM: Microvessel density is a prognostic indicator for patients with astroglial brain tumors. Cancer 1996, 77:362-372.

27. Shibata A, Nagaya T, Imai T, Funahashi H, Nakao A, Seo H: Inhibition of NFkappaB activity decreases the VEGF mRNA expression in MDA-MB-231 breast cancer cells. Breast Cancer Res Treat 2002, 73:237-243.

28. Ueda Y, Nakagawa T, Kubota T, Ido K, Sato K: Glioma cells under hypoxic conditions block the brain microvascular endothelial cell death induced by serum starvation. J Neurochem 2005, 95:99-110.

29. Zhao JX, Yang LP, Wang YF, Qin LP, Liu DQ, Bai CX, Nan X, Shi SS, Pei XJ: Gelatinolytic activity of matrix metalloproteinase-2 and matrix metalloproteinase- 9 in rat brain after implantation of $9 \mathrm{~L}$ rat glioma cells. Eur J Neurol 2007, 14:510-516.

30. Zhang S, Ong CN, Shen HM: Involvement of proapoptotic Bcl-2 family members in parthenolide-induced mitochondrial dysfunction and apoptosis. Cancer Lett 2004, 211:175-188.

31. Cory AH, Cory JG: Lactacystin, a proteasome inhibitor, potentiates the apoptotic effect of parthenolide, an inhibitor of NFB activation, on drugresistant mouse leukemia L1210 cells. Anticancer Res 2002, 22:3805-3809.

32. Wen J, You KR, Lee SY, Song CH, Kim DG: Oxidative stress-mediated apoptosis. The anticancer effect of the sesquiterpene lactone parthenolide. J Biol Chem 2002, 277:38954-38964.

33. Zhang S, Ong CN, Shen HM: Critical roles of intracellular thiols and calcium in parthenolide-induced apoptosis in human colorectal cancer cells. Cancer Lett 2004, 208:143-153.

34. Won YK, Ong CN, Shi X, Shen HM: Chemopreventive activity of parthenolide against UVB-induced skin cancer and its mechanisms. Carcinogenesis 2004, 25:1449-1458.

35. Mathema VB, Koh YS, Thakuri BC, Sillanpää M: Parthenolide, a Sesquiterpene Lactone. Inflammation: Expresses Multiple Anti-cancer and Antiinflammatory Activities; 2011

36. Kim JH, Liu L, Lee SO, Kim YT, You KR, Kim DG: Susceptibility of cholangiocarcinoma cells to parthenolide-induced apoptosis. Cancer Res 2005, 65:6312-6320

37. de Graffenried LA, Chandrasekar B, Friedrichs WE, Donzis E, Silva J, Hidalgo M, Freeman JW, Weiss GR: NF-kappa B inhibition markedly enhances sensitivity of resistant breast cancer tumor cells to tamoxifen. Ann Oncol 2004, 15:885-890.

38. Tassorelli C, Greco R, Morazzoni P, Riva A, Sandrini G, Nappi G: Parthenolide is the component of tanacetum parthenium that inhibits nitroglycerininduced Fos activation: studies in an animal model of migraine. Cephalalgia 2005, 25:612-621.

39. Lei ZN, Zeng SL, Wang L, Zhu JB, Li T: Parthenolide inhibits neuroinflammation and promotes neurogenesis in the ischemic striatum following transient middle cerebral artery occlusion in the adult rat brain. Xi Bao Yu Fen Zi Mian Yi Xue Za Zhi 2009, 25:994-997. Chinese.

40. Rummel C, Gerstberger R, Roth J, Hübschle T: Parthenolide attenuates LPSinduced fever, circulating cytokines and markers of brain inflammation in rats. Cytokine 2011, 56:739-748.

doi:10.1186/1471-2407-12-453

Cite this article as: Nakabayashi and Shimizu: Involvement of Akt/NF-KB pathway in antitumor effects of parthenolide on glioblastoma cells in vitro and in vivo. BMC Cancer 2012 12:453.

\section{Submit your next manuscript to BioMed Central and take full advantage of:}

- Convenient online submission

- Thorough peer review

- No space constraints or color figure charges

- Immediate publication on acceptance

- Inclusion in PubMed, CAS, Scopus and Google Scholar

- Research which is freely available for redistribution 